\title{
Revealing the transformatory moment of learning technology: the place of critical social theory
}

\author{
Richard Hall* \\ Department of Library Services, De Montfort University, Leicester, UK
}

(Received 28 January 2011; final version received 14 September 2011)

\begin{abstract}
In revealing the transformatory moment of learning technology, a holistic and ongoing critique that is related to a range of socio-cultural factors is required. This critique further uncovers the social relations that frame the place of learning technology in bourgeois capitalist work and the development of the knowledge economy. This article argues that critical social theory, and the social and power relationships that it highlights, is central to the uncovering of this revelation. As a result of a holistic, or totalising, analysis based upon the political economy of technology in education, a framework that enables educators to examine its educational value is uncovered. Iterating and re-producing this framework works as a constant critique of educational practice within capitalism, and critiques deterministic or hegemonic views of technology-as-progress. As a result, this article seeks to demonstrate how critical social theory might enable educators to analyse learning technology as historically situated, and thereby to use critique to reveal and produce practical alternatives to sociocultural problems.
\end{abstract}

Keywords: critical social theory; learning technology; education; transformation; political economy

\section{Introduction}

The theoretical positioning of technology in education has typically been addressed with an eye on a specific disciplinary or conceptual focus. So theoretical positions have developed that are, for instance: tied to educational psychology (Bruner 1990; Papert 1980; Ravenscroft and Boyle 2010); socio-culturally oriented, for example in terms of communities of practice (Wenger, White, and Smith 2009) or agendas of personalisation (Attwell and Costa 2009); or political (Dyer-Witheford 1999; Facer and Sandford 2010; Hall 2008). These latter, political critiques begin to work in a trans-disciplinary manner, and are particularly apposite as they focus upon the place of technology in relationships of power and agency (Foucault 1977; Giroux 2010), and look towards the place of technology in possible futures (Facer and Sandford 2010). Addressing the political opens up a set of theoretical positions through which it is possible to understand and develop critiques of hegemonic discourses of the place of technology in education (Gramsci 1971). Moreover, they open up moments in which dominant, emergent narratives of the essence of technological progress can be revealed, alongside subjugated positions.

*Email: Rhall1@dmu.ac.uk; see also http://www.learnex.dmu.ac.uk/celt/celt-people/richardhall-dmu-e-learning-co-ordinator/ 
This revealing of the positional and political nature of technology within social networks or social relationships has been analysed in terms of control (Adorno 1991; Dyer-Witheford 1999; Foucault 1977; Tiqqun 2001; Weber 1969; Zimmerman 1990), or as a socio-cultural construct (Feenberg 1999; Selwyn 2010). Central to an understanding of these theoretical positions is a critique of the contribution of learning technology to the idea of the dominant political economy. The hegemonic position accepts that capitalism, or business-as-usual, is a given, and that learning technology might enable liberal educators to improve the working of education within capital to make it more democratic (Žižek 2009). There is little sense that a critique of learning technology should be used to reveal: the coercive and neoliberal nature of capitalism as revealed in education (Canaan and Shumar 2008); the need for democratic, social intellectuality (Negri 1989; Neary and Winn 2009); the forms of higher education that capital demands (Amsler and Canaan 2008); or the ideology of student-as-consumer (Neary and Hagyard 2010; Noble 1998).

This article argues that critical social theory is central to a meaningful theory of the place of learning technology in the idea of the University (Hall 2010a). The revelation of the political nature of technology in education, tied to the social and power relationships that it enables and replicates, is critical in developing a framework that underpins its educational value. This position works as a constant critique of educational practice within capitalism (Marx 1992), and it does not accept deterministic or hegemonic views of technology-as-progress (Gramsci 1971), but analyses learning technology as historically situated (Feenberg 1999).

\section{Technological determinism and business-as-usual}

Technological determinism runs two ways, in either highlighting the essential value of the utopian functions and forms of a technology or its implementation, or in revealing dystopian views of a controlled existence that is to be resisted. In analysing these positions, Feenberg argues that:

Pure technical principles do not define actual technologies. They must be concretized through a technically realized conception of the good which particularizes them and establishes them systematically in the life process of a society. Every instantiation of technical principles is socially specific. $(1999,180)$

As a result, Feenberg develops a duality of 'primary' and 'secondary instrumentalisations' of technology, with the former including the functions of technical subjects and objects, and the latter focusing upon the integration of technologies within socio-cultural systems and nature, including their role in the social organisation of work and use. The focus on social relations is critical in moving away from fetishising technology "as a non-social instantiation of pure technical rationality rather than as a node in a social network. Essentialism theorizes this form and not the reality of technology" (Feenberg 1999, 211).

The reality of technology in education is revealed by theorising its implementation in light of both the complex spaces in which it is used and its socio-cultural impacts. Critique is central to an understanding of the interplay between technologies, education and modernity, as a historically-situated construct. Focusing on this complexity enables uncritical, essentialist discourses of technology as progress to be challenged. Selwyn $(2010,67)$ begins to address this challenge in arguing that 
educators need to theorise "educational technology as a profoundly social, cultural and political concern". For Hemmi, Bayne, and Land (2009), the use of educational technology is problematic in engaging with change because the institutionalisation of Web 2.0 technologies actualises a reclamation and regulation of innovation within business-as-usual. Such an approach engages with the validity of minority views against hegemonic narratives, which may be alienating.

In terms of educational technology, these hegemonies often focus upon orthodoxies of assessment, collaboration and formal learning, and they do not enable a critical engagement with what Facer and Sandford $(2010,75)$ have called "the chronological imperialism of accounts of inevitable and universal futures". Moreover, they neglect "the extensive deployment by capital of information technologies computers and telecommunications - in order to achieve unprecedented levels of workplace automation, global mobility and societal surveillance" (Dyer-Witheford 2004, 5). The lack of a deeper historical social theory enables a narrative of business-as-usual to underpin an uncritical reading of allegedly emergent innovations in learning technology, like game-based or locative learning, the development of personal learning environments or open educational resources (OERs). One outcome is a form of moral relativism, where particular techno-cultural values or approaches carry hegemonic power (Giroux 2005; Gramsci 1971).

One risk in an untheorised position around learning technology is the uncritical co-option of technology as progress to a neoliberal educational agenda, in which specific tools or media are positioned unequivocally as transformatory (Bonk 2010; Department of Business, Innovation and Skills 2009; Higher Education Funding Council for England 2010; Willetts 2010). Uncontested claims for the opportunities offered by digital technologies appear as justifications for the growth of the technological economy or technocracy within higher education (New Media Consortium 2010; Teaching and Learning Research Programme 2010). Thus, Crook and Joiner $(2010,1)$ highlight that whilst institutional or societal capacity and capability for the take-up of technology in education are crucial, there is "a recurring discomfort that these translations are not more widely taken up - that the education system fails to embrace new technologies with adequate enthusiasm". At issue here is either projection from the present into an idealised future, or a focus on a promise of educational technology that clouds or ignores the complexities of our sociocultural realities. This reflects Ravenscroft's $(2009,1)$ view that practitioners need to consider "the current technological innovations as players in an evolving paradigm, and not necessarily clear solutions to well-understood problems". At issue here is the complexity of the educational experience of technology and its situation within a historically-situated, political economy (Dyer-Witheford 1999).

By examining the socio-cultural spaces in which technology is deployed, educators and students can critique analyses that promote the consumption of a specific set of tools that are owned or celebrated by dominant players, and which are often predicated upon ideologies of personal development that are primarily economic and increasingly privatised or outsourced (Hall 2010b). This homogenisation of experience frames technologies as transformatory without a critique of the sociocultural forms in which they are used, and risks trivialising access to and use of technology for revolutionising the social relations and associations within which they are used. Are those who speak of technology as revolutionary talking about new activities within new social forms as a result of such engagements? If not, is this use of technology truly revolutionary? Such an analysis requires a critique 
grounded in social theory, in order to uncover nuances of power and control, of participation and marginalisation, and of inequity (Feenberg 1999; Noble 1984; Säljö 2010).

\section{Technology and political economy}

For Marx (1992, 286), technology was central to the social relationships that develop historically between different classes of people. In understanding the critical theoretical role of technology, Marx analysed how it underpinned capitalist social relations through labour's productive power:

It is not what is made but how [it is made], and by what instruments of labour, that distinguishes different economic epochs. Instruments of labour not only supply a standard of the degree of development which human labour has attained, but they also indicate the social relations within which men work. $(1992,286)$

The social relations embedded in, and revealed by, capitalist work, are central to a theoretical critique of learning technology; for instance, in terms of the production of games or learning spaces, the creation of OERs, or the support for placement work in a knowledge economy. There is a dialectical interplay between technologies and social relations, which is important in critical political economy because of the ways in which the former both reduces socially necessary labour time, in order to increase value, and extends relative surplus value (Harvey 2010), as well as commodifying and dispersing the productive power of labour (Negri 1989). In terms of a narrative of business-as-usual, the result of these connections is the emergence of an ideology of technology underpinning economic efficiency and progress, and social mobility, which in turn impact education because that sector is implicated in descriptions of capitalist economic growth (Browne 2010; Willetts 2010).

A starting point for a critique of the place of learning technology within capitalist higher education is socially necessary labour time, which Marx (1992) viewed as the source of all value. Rather than being conceived of as units of labour measured in hours or days, it is conceived as the amount of labour time required by a worker (or academic/student) of average productivity (and therefore skill), working with tools (like learning technologies) of the average productive potential, required to produce a given commodity (such as OER, feedback on assessment or journal article). Thus, in the higher education context, more-skilled academics reduce the average time and increase productivity, whilst unskilled academics contribute less social value. The current discourse around the knowledge economy, focused upon generating new, technical skills for jobs that have not yet emerged in the name of economic growth, forms part of this agenda (Newfield 2010). Newfield (2010, 1112) points out that the main issue in this discourse is the employers' ability to extract value by managing the scarcity of "knowledge-based star producers" and harnessing their output.

Revealing the uses of learning technology in light of a critical social theory focused upon increased productivity and reduced socially necessary labour time enables value to be seen as a complex social relation, rather than a material practice, such as: a given amount of human activity, like the number of class contact hours; an object that can be commodified, like a mobile app; or, a personal experience, like student satisfaction ratings (Marx 1992). Value is a relationship between 
people organised into a society, and in our current, historical form that is abstract labour within capitalist work (Postone 2009). In higher education, as in society more broadly, it is through the repetition of technology and its automation of creative tasks that academic work becomes abstracted from the staff and students engaged in those practices. This level of abstraction of the academic's labour-power from the process and reality of capitalist work enables social domination, which is impersonal, increasingly rationalised, and managerially constrained. For Newfield $(2010,14)$ technology in the knowledge economy reveals how the autonomy and agency of academics and students as knowledge workers can be marginalised where they have no proprietary knowledge that adds to a university's relative surplusvalue. Whilst machines bind partial academic processes together into a whole, reduce idle time and maintain the continuity of production of research or teaching spaces, they also homogenise and de-skill that production (Marx 1973). Moreover, they enable capital, in the various forms of higher education, to disperse production organisationally through home-working, outsourcing and privatisation into society, in order to remove academic labour's collective, social power (Negri 1989).

As education is increasingly implicated in discourses of economic growth, learning technology is critical because it impacts skills and productivity in the production of surplus value, which can then be used to reproduce capital and capitalist social relations (Dyer-Witheford and de Peuter 2009). The reality is that, within capitalism, learning technology enables productive but not proprietary knowledge to be privatised or outsourced (Newfield 2010), and increases the alienation of the academic from the value of her labour-power. Such alienation is tied to commodification, through increases in the monitoring of devolved activity, the repetition and ossification of work, the imperative to materialise activity through sharing, re-use and re-production, and the outsourcing of services, in the name of increased value for the institution. Within critical social theory, the commodity, like a widget or OER, is a unity that has a dual aspect: the first describes its use-value to an individual, or its function; and the second is its exchange-value in relation to other commodities or use-values. This dual aspect helps define value as socially necessary labour time, as commodities can be exchanged in the capitalist form of social relationships by dint of their use-value. Thus, the role of technology in the commodification of academic life is central, either in terms of controlling and monitoring labour or work or in the production of resources that can be consumed by students (Dyer-Witheford and de Peuter 2009; Harvey 2010; Lebowitz 2003; Postone 2009). Within education, technology impacts productivity, and enables the circulation of commodities like abstracted knowledge in the form of on-line courses or resources, or apps for mobile devices (Hall and Winn forthcoming, 2011).

More generally, control over the labour-power of others enables the capitalist to accrue relative surplus-value. Surplus-value is the social value of a commodity that is over and above what is required for the producers of it to live. As long as the capitalist has a superior technology in relationship to others, she can accumulate relative surplus-value. However, as soon as a new method of production is generalised it removes any differences between the individual value of a cheapened commodity and its social value, and the amount of relative surplus-value vanishes. This works for technology in education, as a means of competitive advantage between providers through local innovation, and for the sector as a means of creating value for a capitalist economy. As the coercive law of competition forces competitors to adopt the same methods (Marx 1992), the business benefits of deploying a specific 
technology in university environments will lead to relative surplus-value until other universities mirror that deployment. At that point a barrier to growth and relative surplus-value, in the form of cognitive or financial capital, is reached, and new spaces for technological growth are required; for instance, through internationalisation. As a result, the hegemonic narrative of progress is connected to the fetish belief in a "technological fix", as an answer to poor economic growth or low productivity (Clarke 1994; Harvey 2010), and this creates a relentless 'treadmill dynamic' to chase the next technocratic innovation (Postone 2009). In education, this dynamic is seen in the drive for constant technological change and the search for 'the next Twitter' (Gartner 2010), as opposed to a focus on the relative strength of academic labour in its co-option of technologies to resist control, and to transform the institution and its social relations through co-production (Dyer-Witheford 2004; Higher Education Academy 2011).

\section{The critical position of learning technology}

Lukács (1972) identified the value of critical social theory in providing a totality of historically-situated social reproduction that was all-pervasive. Within this totality, the parts of the system, like culture and economic relations or technology, acquire properties that have meaning, in relation to connection and dialectical analysis (Lebowitz 2003). As Marx noted:

Technology reveals the active relation of man to nature, the direct process of the production of his life, and thereby it also lays bare the process of the production of the social relations of his life, and of the mental conceptions that flow from those relations. $(1992,493)$

In this view, learning technology is implicated in a broader totality or production, consumption and re-production of social relations, which is historically situated with capitalism. This totality is in constant flux and motion (Neary and Taylor 1998; Postone 2009), and reveals "the annihilation of space by time" (Marx 1973, 524). This, control over technology is one means by which the reproduction of the capitalist work can be assured, and it is on this basis that a critique of learning technology through critical social theory rests.

Examining this totality is central to generating a critique of the capitalist modes of production and consumption, within which the role of technology is invested. Harvey (2010) argues that there are seven activity areas that underpin meaningful social change:

(1) Technological and organisational forms of production, exchange and consumption.

(2) Relations to nature and the environment.

(3) Social relations between people.

(4) Mental conceptions of the world, embracing knowledges and cultural understandings and beliefs.

(5) Labour processes and production of specific goods, geographies, services or affects.

(6) Institutional, legal and governmental arrangements.

(7) The conduct of daily life that underpins social reproduction. 
Akin to Lefebvre's (1968) "ensemble" or Deleuze's (1994) "assemblage" of moments co-evolving in an open, active, dialectical manner, Harvey's model highlights that holistic social change is necessary, and that achieving such change is complex, and beyond the revolutionary potential of technology alone. Harvey highlights how technology is tied to organisational forms, both in and beyond the institution, and that it is impacted by social, environmental and political-economic effects, relations and conceptions. This places technology firmly within a broader range of life experiences in the lived, capitalist world (Dyer-Witheford 2004; Habermas 1987).

Moreover, the nature of these lived experiences is social, and not personal. Marx $(1973,1992)$ argued that cooperation and combination were central to increasing the forces of production, and our ability to transform the world. This division and cooperation of labour beyond specific working contexts (Negri 1989) mirrors the need for real-world engagements and associations using learning technologies (Hall 2008), and extends a critique of personal learning environments or games towards cooperative learning (Bandura 1995; Parajes 1996). Marx stressed the combination of labour as the source of social productivity and the separation of workers as the condition for their exploitation (Negri 1989; Lebowitz 2003). Technology was one way in which workers can be separated in the production of their lives, as an embodiment of capitalist relations of production (Marx 1992). In this way, without a critique of the totality of social re-production, the constant striving for technological innovation can be seen as a means of alienating workers from both their labour-power and the possibilities of cooperation, whilst further commodifying the production of their lives, in terms of education, health and social care (Dyer-Witheford 2004).

At issue for understanding the transformatory nature of learning technology is recognising the need to engage politically and critically across each of these activity areas in a way that is sensitive to context, be that autonomous or socialised. It is not enough to present a simple, atheoretical description of educational practices with technology that form a simple causal model. The risk is that such an uncritical approach merely mandates a focus on technological change that supports efficiency and growth. Thus, as was noted in the previous section, the implementation of learning technology is implicated in the struggle between capitalists, and between capital and labour, over relative surplus-value, which explains why capitalism has to be so technologically-dynamic (Dyer-Witheford 1999; Lebowitz 2003; Negri 1989).

Of course, this risks the alienation of workers from new technologies, as witnessed by those who criticise academics who do not engage fully with learning technology (Bonk 2010) or in reaction to spaces that privilege emergent technical skills (Joint Information Systems Committee 2010). The constant evolution of learning technologies, as consistent with emerging norms of educational production, forces innovation elsewhere; for example, in administrative spheres. Moreover, technologies discipline labour and create a labour surplus that depresses wages and aspirations. This increases the hegemonic hold of those who control production through knowledge technologies and technical processes within capitalist work, and of innovative or emergent or immersive learning technologies in capitalist education (Tiqqin 2001). These differences impact how work is constructed, and how it is perceived and valued. As a result, it is possible that the institutionalisation of learning technologies becomes alienating precisely because "it is just another way of creating capital out of immaterial labour" (Winn 2010). It is impossible to evaluate the impact of learning technologies without addressing their 
place in the totality of social production, related to the value of that experience as capitalist work. The demand, therefore, is to re-imagine a social form/set of relationships within which technology functions for equality rather than coercive competition and accumulation.

\section{Theorising a critical politics of learning technology}

An engagement with the possibilities of critical social theory enables activistacademics and students to examine collectively their 'power-to' change their social relations, rather than to exist in a state where some-one or some-thing has 'powerover' both their work and their selves (Holloway 2002). For Marx (1973), it was labour's control over the machine or technology, however limited, that gave workers a moment of resistance to the totalising alienation of capitalist work. This uncovers a political moment that sits against the economic narrative of knowledge economy, value-for-money, more-for-less and efficiency. As a form of praxis such engagements are hopeful, and Giroux $(2010,1)$ notes that hope is a critical value in this process: "Hope makes the leap for us between critical education, which tells us what must be changed; political agency, which gives us the means to make change; and the concrete struggles through which change happens". One outcome of a theoretical engagement with the relationship between socio-cultural critique and learning technology is that the self-evident laws of capitalist production, which act as a brake on resistance, might be overcome (Marx 1992).

The possibilities of learning technologies for association, resistance and re-imaging or re-production of society need to be theorised, in terms of the contradictions and barriers of capital. The deeper structures of capital work dialectically to ensure that crises or barriers, like under-consumption, over-production, or a falling rate of profit, are overcome (Clarke 1994). However, in the face of massive disruptions like resource availability and costs, financial crises and lower living standards, and change, the activity areas in the totality outlined by Harvey (2010) are all radically affected by the historical dynamics of capital (Postone 2009). This means that hegemonic discourses of power, production and relationships are revealed and questioned (Gramsci 1971), and that the development of theorised, counter-hegemonic positions is vital. The social, cooperative structures enabled by learning technologies are pivotal in capturing the power released the motion of capital, and in reproducing a shared set of educational and societal alternatives.

In terms of learning technology, a critical social theory that connects with such counter-hegemonic positions must connect with a critique of the totality of capitalist work and social relations. The following conceptual spaces demonstrate how social forces might be organised and make use of theoretical critiques.

Student-as-producer (Higher Education Academy 2011), which "extends the concept of production to include ways in which students, as social individuals, affect and change society, so as to be able to recognise themselves in the social world of their own design".

- The Really Open University's (2010) emphasis on the need for praxis, in reasserting the idea of the university as a site for critical action, resistance and opposition, led by students.

- The Peer to Peer University's (2010) and the Social Science Centre's (2011) approaches to cooperative production through sharing and accreditation. 
- Our ability to produce spaces for the activity and labour of (self-)discovery and (self-)invention by re-fashioning democratic and participative social relationships (Negri 1989).

- The Institute of Collapsonomics' (2010) analysis of meaningful socio-cultural resilience, and our capacity to develop agile and mobile associations, which can solve problems and develop alternatives.

These more activist spaces enable a cooperative critique of the connections between learning technology, environmental demands and human needs, in order to practice alternatives. Marx (1973) argued that the many-sided needs of the social human being can be met through cooperation and co-production of meaningful and authentic use-values and social relations. However, this requires the radical transformation of society away from capitalism, which demands a theorising of education and technology-in-education that is not framed by business continuity (i.e. ensuring 'business-as-usual'). It demands a critical social theory that engages with wider societal changes, and how those might be reflected by changes in the mutual aspirations of staff and students and their (non-)use of technology, and in their understanding of and response to a dramatically changing world (Greer 2011; Tiqqun 2001; Winn 2010). This view maps onto Noble's (1984) belief that the development and use of technology in education is inherently political, and that it needs to be revealed as socially constructed and indeterminate. There is then a balance to be struck between access-to and power-over technology and the resources embedded in its production, and the uses to which it can be put by researchers, teachers and students, for social struggle and against politically-motivated technological determinism, in the hopeful search for change (Giroux 2010; Tiqqun 2001).

In overcoming the alienation of capitalist work, debating and fighting for the idea and the form of the university, infused with and by a culture of open critique, is vital. Such resistance might usefully be centred on deliberating the social relations that enable learners and tutors as labour to engage with disruption, rather than situating education within neoliberal business models. Such resistance demands a critical, theoretical stance be taken that incorporates and reveals the place of learning technology within the whole. As Lukács noted of critical social theory:

Proletarian science is revolutionary not just by virtue of its revolutionary ideas which it opposes to bourgeois society, but above all because of its method. The primacy of the category of totality is the bearer of the principle of revolution in science. $(1972,27)$

\section{Conclusion}

At issue, then, is a critique of the place of learning technology in the cause of our educational provision, and our social transformation, rather than viewing learning technology as neutral and as an input into libertarian educational production (Noble 1984). Such a critique must be founded upon deeper understandings of the mutual, socio-cultural contexts within which technology is deployed (Selwyn 2010), underpinned by political economy (Hall 2010b), and a critique of the neoliberal educational project that promotes higher education as consumption (Amsler and Canaan 2008; Neary and Hagyard 2010; Noble 1998). In this way the interplay between learning technologies and the production of educational relationships is central, and is tied to a contextual, historical critique of the communal, associational uses of those technologies. As Marx noted: 
only in association with others has each individual the means of cultivating his talents in all directions. Only in a community therefore is personal freedom possible ... In a genuine community individuals gain their freedom in and through their association. (Quoted in Bottomore and Rubel 1974, 63-64)

Taking a critical social perspective enables us to overcome the subsumption of learning technology for humanist ends to an essentialist discourse of the knowledge economy, economic efficiency, and value-for-money (Department of Business, Innovation and Skills 2009; Newfield 2010; Willetts 2010). Thus, both technological development and emerging educational forms, which are seen as catalysts for unsustainable discourses of 'innovation' and 'efficiency', demand critique through the lens of political economy. Critical social theory recognises that human beings are not static and that their integration and adoption of technology is equally in motion (Negri 1989; Postone 2009). Moreover, in the face of socio-environmental disruptions like climate change, sustainable discourses of the idea of higher education, and the place of learning technologies in that idea are required.

A theoretical perspective of the role of learning technology enables academicactivists and student-activists to critique how those tools are used in capitalist work to mediate production and consumption, and an authentic, lived reality. As Postone $(2009,34)$ notes, critical social theory "is a transhistorical - and commonsensical understanding of labor as an activity mediating humans and nature that transforms matter in a goal-directed manner and is a condition of social life". A critique of the place of technology in education must incorporate the social relations of production and consumption of that lived reality. In the face of global disruption, a radical critique of those social relations holds the possibility of revolutionary transformation through the process of self-creation and praxis within the commune (Marx 1973). This is a final challenge for a critique of the place of learning technology in the idea of the university: how can the individual nature of educational production, accreditation and experience be socially negotiated? How can social wealth accrue to freely associating individuals for communal ends? In engaging theoretically with these questions, it may be possible to use learning technology to produce practical alternatives.

\section{References}

Adorno, T.W. 1991. The culture industry: Selected essays on mass culture. London: Routledge.

Amsler, S.S., and J. Canaan. 2008. Whither critical education in the neoliberal university? Two practitioners' reflections on constraints and possibilities. Enhancing Learning in the Social Sciences 1, no. 1. http://bit.ly/bSQ8KY.

Attwell, G., and C. Costa. 2009. Integrating personal learning and working environments. Bristol: Futurelab. http://www.beyondcurrenthorizons.org.uk/wp-content/uploads/ch4_attwell_graham_integratingworkandpersonallearning20090116.pdf.

Bandura, A. 19995. Self-efficacy in changing societies. Cambridge: Cambridge University Press.

Bonk, C.J. 2010. Overcoming the technology resistance movement: 10 ideas. http://travelinedman.blogspot.com/2010/01/overcoming-technology-resistance.html.

Bottomore, T.B., and M. Rubel. 1974. Karl Marx: Selected writings in sociology and social philosophy. London: Penguin.

Browne, Lord. 2010. Independent review of higher education funding and student finance. $\mathrm{http}: / /$ hereview.independent.gov.uk/hereview/report/.

Bruner, J. 1990. Acts of meaning. Cambridge, MA: Harvard University Press. 
Canaan, J.E, and W. Shumar, eds. 2008. Structure and agency in the neoliberal university. London: Routledge.

Clarke, S. 1994. Marx's theory of crisis. Basingstoke: Macmillan Press.

Crook, C., and R. Joiner. 2010. 'CAL' - Past, present and beyond. Journal of Computer Assisted Learning 26, no. 1: 1-3.

Deleuze, G. 1994. Difference and repetition. New York: Columbia University Press.

Department of Business, Innovation and Skills. 2009. Higher ambitions. http://webarchive. nationalarchives.gov.uk/+/http://www.bis.gov.uk/policies/higher-education/shape-andstructure/higher-ambitions.

Dyer-Witheford, N. 1999. Cyber-Marx: Cycles and circuits of struggle in high technology capitalism. Chicago: University of Illinois Press.

Dyer-Witheford, N. 2004. Autonomist Marxism and the information society. Canberra: Treason Press. http://libcom.org/library/autonomist-marxism-information-society-nick-witheford.

Dyer-Witheford, N., and G. De Peuter. 2009. Games of empire: Global capitalism and video games. Minneapolis, MN: University of Minnesota Press.

Facer, K., and R. Sandford. 2010. The next 25 years?: Future scenarios and future directions for education and technology. Journal of Computer Assisted Learning 26, no. 1: 74-93.

Feenberg, A. 1999. Questioning technology. London: Routledge.

Foucault, M. 1977. Discipline and punish. The birth of the prison. London: Penguin Books.

Gartner. 2010. Hype cycles 2010 special report. http://www.gartner.com/technology/research/ hype-cycles/.

Giroux, H.A. 2005. Border crossings: Cultural workers and the politics of education. London: Routledge.

Giroux, H.A. 2010. When hope is subversive. Tikkun 19, no. 4: 1-4. http://www.henryagiroux.com/online articles/Tikkun\%20piece.pdf.

Gramsci, A. 1971. Selections from the prison notebooks. London: Lawrence and Wishart.

Greer, J.M. 2011. The onset of catabolic collapse. http://www.energybulletin.net/stories/201101-20/onset-catabolic-collapse.

Habermas, J. 1987. Lifeworld and system: A critique of functionalist reason. Vol. 2 of The theory of communicative action. Boston: Beacon Press.

Hall, R. 2008. The impact of the read/write web on learner agency. E-learning 5, no. 3: 284-96.

Hall, R. 2010a. Reimagining the university: Autonomous and co-operative re-production. http://www.learnex.dmu.ac.uk/2010/11/29/reimagining-the-university-autonomous-and-cooperative-re-production/.

Hall, R. 2010b. A revised note on technology, outsourcing and the privatisation of higher education. http://www.learnex.dmu.ac.uk/2010/12/14/a-revised-note-on-technology-outsourcingand-the-privatisation-of-higher-education/.

Hall, R., and J. Winn. 2011. Questioning technology in the development of a resilient higher education. E-Learning and digital media, forthcoming.

Harvey, D. 2010. A companion to Marx's capital. London: Verso.

Hemmi, A., S. Bayne, and R. Land. 2009. The appropriation and repurposing of social technologies in HE. Journal of Computer Assisted Learning 25, no. 1: 19-30.

Higher Education Academy. 2011. Student as producer. http://studentasproducer.lincoln.ac.uk/.

Higher Education Funding Council for England. 2010. Online learning taskforce. http:// www.hefce.ac.uk/learning/enhance/taskforce/.

Holloway, J. 2002. Change the world without taking power. London: Pluto Press.

Institute of Collapsonomics. 2010. The Institute of Collapsonomics. http://collapsonomics.org/.

Joint Information Systems Committee. 2010. Open educational resources programme. http:// www.jisc.ac.uk/whatwedo/programmes/elearning/oer.aspx.

Lebowitz, M.A. 2003. Beyond capital: Marx's political economy of the working class. Basingstoke: Palgrave Macmillan.

Lefebvre, H. 1968. Dialectical materialism. London: Jonathan Cape.

Lukács, G. 1972. History and class consciousness: Studies in Marxist dialectics. Cambridge, MA: MIT Press.

Marx, K. 1973. Grundrisse. St Albans: Paladin.

Marx, K. 1992. Capital, Volume 1: A critique of political economy. Harlow: Penguin. 
Neary, M., and A. Hagyard. 2010. Pedagogy of excess: An alternative political economy of student life. In The marketisation of higher education: The student as consumer, ed. M. Molesworth, L. Nixon, and R. Scullion, 209-24. London: Routledge.

Neary, M., and G. Taylor. 1998. Money and the human condition. Basingstoke: Palgrave Macmillan.

Neary, M., and J. Winn. 2009. Student as producer: Reinventing the undergraduate curriculum. In The future of higher education: Policy, pedagogy and the student experience, ed. M. Neary, H. Stevenson, and L. Bell, 192-210. London: Continuum.

Negri, A. 1989. The politics of subversion: A manifesto for the twenty first century. Cambridge: Polity Press.

Newfield, C. 2010. The structure and silence of cognitariat. Edufactory webjournal 0 issue: 10-26. http://www.edu-factory.org/edu15/webjournal/n0/Newfield.pdf.

New Media Consortium. 2010. Horizon report 2010. http://www.nmc.org/pdf/2010-HorizonReport.pdf.

Noble, D.F. 1984. Forces of production: A social history of industrial automation. New York: Alfred A. Knopf.

Noble, D.F. 1998. Digital diploma mills: The automation of higher education. First Monday 3, no. 1. http://firstmonday.org/htbin/cgiwrap/bin/ojs/index.php/fm/article/view/569/490.

Papert, S. 1980. Mindstorms: Children, computers, and powerful idea. New York: Basic Books.

Parajes, F. 1996. Self-efficacy beliefs in academic settings. Review of Educational Research 66, no. 4: 543-78.

Peer to Peer University. 2010. About P2PU. http://p2pu.org/.

Postone, M. 2009. Rethinking Marx's critical theory. In History and heteronomy: Critical essays, UTCP Booklet 12, ed. M. Postone, V. Murthy, and Y. Kobayashi, 31-47. Tokyo: The University of Tokyo Center for Philosophy.

Ravenscroft, A. 2009. Social software, Web 2.0 and learning: Status and implications of an evolving paradigm. Journal of Computer Assisted Learning 25, no. 1: 1-5.

Ravenscroft, A., and Boyle, T. 2010. Deep learning design for technology enhanced learning. Paper presented at the International Conference on Educational Media, June 29-July 2, in Toronto, Canada. http://altc2010.alt.ac.uk/attachments/0001/1840/DLD-AR_TB_fsub1_d_.pdf.

Really Open University. 2010. The Really Open University. http://reallyopenuniversity.wordpress.com/.

Säljö, R. 2010. Digital tools and challenges to institutional traditions of learning: Technologies, social memory and the performative nature of learning. Journal of Computer Assisted Learning 26, no. 1: 53-64.

Selwyn, N. 2010. Looking beyond learning: Notes towards the critical study of educational technology. Journal of Computer Assisted Learning 26, no. 1: 65-73.

Social Science Centre. 2011. A new model for higher and co-operative education. http:// socialsciencecentre.org.uk/.

Teaching and Learning Research Programme. 2010. Digital literacies research briefing. http://www.tlrp.org/docs/DigitalLiteracies.pdf.

Tiqqun. 2001. The cybernetic hypothesis. http://www.archive.org/details/Tiqqun1.

Weber, M. 1969. The theory of social and economic organization. New York: Macmillan.

Wenger, E., N. White, and J.D. Smith. 2009. Digital habitats: Stewarding technology for communities. Portland, OR: CPSquare.

Willetts, D. 2010. Speech to Universities UK Annual Conference. http://nds.coi.gov.uk/content/Detail.aspx?ReleaseID $=415386 \&$ NewsAreaID $=2$.

Winn, J. 2010. Open education and sustainability. http://joss.blogs.lincoln.ac.uk/2010/07/23/ open-education-and-sustainability/.

Zimmerman, M.E. 1990. Heidegger's confrontation with modernity: Technology, politics, art. Bloomington: Indiana University Press.

Žižek, S. 2009. First as tragedy, then as farce. London: Verso. 